\title{
Character Education in Physical Education Learning Model: A Bibliometric Study on 2011-2020 Scopus Database
}

\author{
Tatang Muhtar*, Tedi Supriyadi, Anggi Setia Lengkana, Sulthan Hadist Ismaiedh Cukarso \\ Physical Education of Elementary School Teacher Education Study Program, Universitas Pendidikan Indonesia, Bandung, Indonesia
}

Received August 31, 2021; Revised October 3, 2021; Accepted November 5, 2021

\section{Cite This Paper in the following Citation Styles}

(a): [1] Tatang Muhtar, Tedi Supriyadi, Anggi Setia Lengkana, Sulthan Hadist Ismaiedh Cukarso, "Character Education in Physical Education Learning Model: A Bibliometric Study on 2011-2020 Scopus Database," International Journal of Human Movement and Sports Sciences, Vol. 9, No. 6, pp. 1189 - 1203, 2021. DOI: 10.13189/saj.2021.090613.

(b): Tatang Muhtar, Tedi Supriyadi, Anggi Setia Lengkana, Sulthan Hadist Ismaiedh Cukarso (2021). Character Education in Physical Education Learning Model: A Bibliometric Study on 2011-2020 Scopus Database. International Journal of Human Movement and Sports Sciences, 9(6), 1189 - 1203. DOI: 10.13189/saj.2021.090613.

Copyright $\bigcirc 2021$ by authors, all rights reserved. Authors agree that this article remains permanently open access under the terms of the Creative Commons Attribution License 4.0 International License

\begin{abstract}
Literature shows that character and physical educations, to enhance students' fitness and growth through physical activity, have a vital role in the learning process. A character-based physical education learning model is required to integrate the two educational ideas. A study on the development of research on this topic is required for the model's application and development. Therefore, this study aims to find and analyze articles in Scopus indexed journals of the last decade (2011-2020) related to character-based physical education learning models. In this study, a bibliometric analysis was employed to explore the roadmap for character-based physical education learning. This bibliometric study has four steps: (1) finding related articles, (2) filtering, (3) validating and completing the article information, and (4) carrying out a bibliometric analysis. This study discovered eight findings, including: (1) publication trend of the physical education learning model in 2011-2020; (2) citation number of the article; (3) author collaboration; (4) the most used keywords by the authors; (5) abstract analysis; (6) institutional collaboration; (7) country analysis; and (8) analysis of character values promoted in the bibliography. Based on these eight findings, this study concludes that academics and researchers pay insufficient attention to character-based physical education learning models. This also suggests that in the context of physical education learning, their attention is more concentrated on the cognitive and psychomotor domains. On the other hand, academics have not paid much
\end{abstract}

attention to character as an effective area. This finding needs to be highlighted because, in education, besides knowledge, an educator has a duty to transfer values. Therefore, more publications on the integration of character education into physical education are required. This study can assist in mapping future research directions that will encourage further research on physical education.

Keywords Bibliometrics, Character, Learning Model, Physical Education

\section{Introduction}

Character education has become an important part of educational development and a strategic policy agenda in educational curricula in various countries [1], [2]. Therefore, morality, character education or moral development, however defined, has been a concern of public schools since its inception [3], [4]. Physical education which in practice cannot be separated from physical activities through sports has a very strategic role in the education world to develop student character. This can be seen from a number of scientific researches produced by a number of academics in various countries and even the inherent ideology of practitioners in the physical education and sports fields carrying the jargon 
mensana in corpore sano or sport builds character [5-7]. However, nowadays these jargons are being sued and questioned [8-10] considering that there are still many phenomena of moral issues that often occur in every sporting match such as beatings of referees, fights between players, adulteration of players, bribery in matches as well as the use of doping by players have become the anxiety of academics. This anxiety was finally addressed by the many scientific researches produced by academics proving the contribution of physical education in promoting good character. Promoting character education through physical education requires a learning model that integrates character education [11]. Based on this, exploring physical education learning models based on character development is important in developing future studies

Recent studies on physical education learning models have been done by several academics, including Pan et al., (2019) who examine the impact of the physical education curriculum model on students by combining Teaching Personal and Responsibility (TPSR), Sports Education Model (SEM), and the Traditional Teaching Model (TTM) [12]. A 16-week pre-test and post-test quasi-experiment on 133 high school students was conducted. In comparison to the TPSR-TTM control group, it was found that TPSR-SEM experimental group has a better result on self-efficacy, sports passion, responsibility, and game performance. The study recommends that the TPSR-SEM model should be applied in the physical education curriculum. Similarly, a study investigated the role of physical education teachers in nurturing religious, nationalist, independent, and cooperative characters [11]. Using action research, the study found a method to nurture those characters in eight steps. Those eight steps are made into acronyms of SPORTIVE (Spiritual, Planning, Organizing, Reflection, and Repetition, Together, Internalization, and Evaluation [11]. On the other hand, the study investigated the physical education learning model that focused on exploring and confirming the factor structure of the physical education learning model, which are disciplined, hardworking, and cooperative [13]. In addition, the study also examines the effectiveness of physical education learning model on elementary students. Using a mixed-method approach involving 50 teachers and 252 elementary school students, it was found that the physical education learning model is able to improve students' characters of disciplined, hardworking, and cooperative [13]. It is further recommended exploring the literature on character-based physical education learning models within the framework of bibliometric studies.

Taking those studies into account, it is believed that this study is important to map bibliographic information from certain fields [14], [15] to examine the direction of development on research related to physical education learning models. Therefore, this study aims to explore the literature on physical education learning models that promote character improvement in Scopus indexed journals from 2011 to 2020 . To achieve the aims of the study, eight questions were formulated:

Q1: How is the development of research on the physical education learning model in 2011-2020?

Q2: How is the development of citation in research on physical education learning model in 2011-2020?

Q3: How is the collaboration between authors in research on physical education learning models in 2011-2020?

Q4: What are the most used keywords in research on the physical education learning model in 2011-2020?

Q5: What are the most widely used abstract terms in research on physical education learning model research in 2011-2020?

Q6: How is the collaboration between institutes in research on physical education learning model in 2011-2020?

Q7: Which countries contributed to the research on the physical education learning model in 2011-2020?

Q8: What character values are promoted in research on the physical education learning model in 2011-2020?

\section{Literature Review}

In concept, character education is a method of nurturing good qualities or values in students so that they have good character performance and morals that manifest in the form of virtue and is ingrained in their daily personalities [16], [17]. It is important because education is not merely knowledge transfer, but it must be a part of life that is carried out consciously based on moral values [18], [19]. Growing and nurturing character values requires tactics, methods, and approaches [20]-[23]. It means that if a learning model is not implemented within the framework of student character development, the intended character values will not be developed through physical education learning [20]-[23].

A learning model is a conceptual framework that outlines procedures or methodical phases in organizing learning experiences to meet certain learning goals and it acts as a guide for learning designers and teachers in planning and implementing learning experiences [24]. In general, a learning model has several characteristics, including (1) having a specific educational mission or goal, (2) can be used as a guideline for improving teaching and learning in the classroom, (3) having parts of the model called: sequence of learning steps (syntax), the existence of reaction principles, social and support systems, (4) having an impact as a result of the application of the learning model, and (5) teaching preparations with the guidelines of the learning model [24]-[26]. Regarding character development through physical education, there are at least six key aspects that can be utilized as guidelines: 1) Education has to be a continuous effort. 2) Student has to take interest in the subject. 3) The activity must satisfy the 
participants. 4) Complete integration should be offered in the activities. 5) The activities have to nurture leadership and followership. 6) The activities have to provide sell-directed opportunities [27].

Competent teachers are required to develop a character-based physical education learning model. The success of physical education in schools is influenced by teacher quality [28]. To develop learning activities, teachers need to have literacy skills that can be nurtured by exploring studies, for example studies on how teacher learning are being researched. Then, they can propose and discuss the learning models that reflect their professionalism [29]-[33]. Furthermore, teachers must constantly reflect on themselves and aim to enhance the learning quality by exploring learning types and teaching styles that can affect the learning process [34]. It has to be conducted so that teachers could learn and grow continuously by developing theories that can be used in the classroom [26], [35], [36]. This process requires the cognitive and emotional involvement of teachers, individually and collectively, for improvement or change for the better [37].

Based on the theoretical framework, it is believed that bibliometric studies are one type of literacy that can encourage teachers to develop their learning process.
Teachers can use this study to map the direction of the most recent studies. Therefore, this bibliometric study could contribute to the mapping of future research directions and encouraging practitioners and academics to conduct further research in the field of character-based physical education learning models.

\section{Methods}

This study employs a bibliometric analysis that adopts a systematic and explicit mapping method [36]-[40]. Bibliometric analysis is a quantitative method aiming to analyze bibliographic data of journal articles. Furthermore, bibliometric method is also used to establish the pattern of writing and citations in a certain location over time and to provide an overview of the location's dynamics [41]-[43]. To analyze the bibliometric data, several programs were used such as Publish or Perish (PoP), EndNote, VOSviewer, GPS Visualizer, and Maps.co [42]-[46]. This study employed four steps, which are bibliography search and examination, bibliography filtering, bibliography refinement and completion, and bibliography analysis [47].

\section{Bibliography Exploration and Examination}

Bibliography

Refinement and

Completion

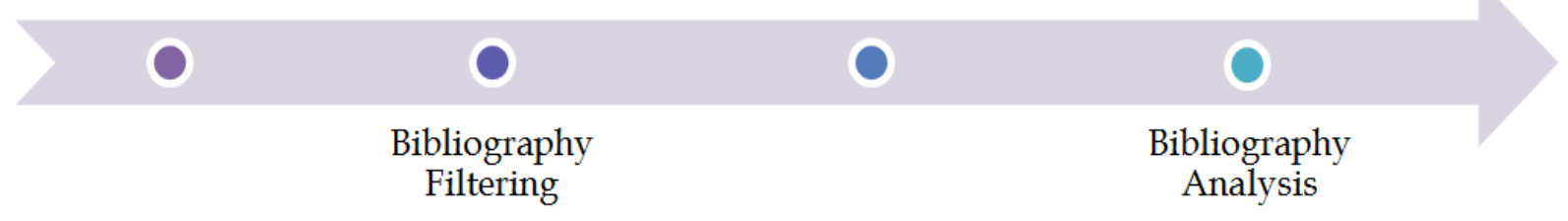

Figure 1. Bibliometric Analysis Steps

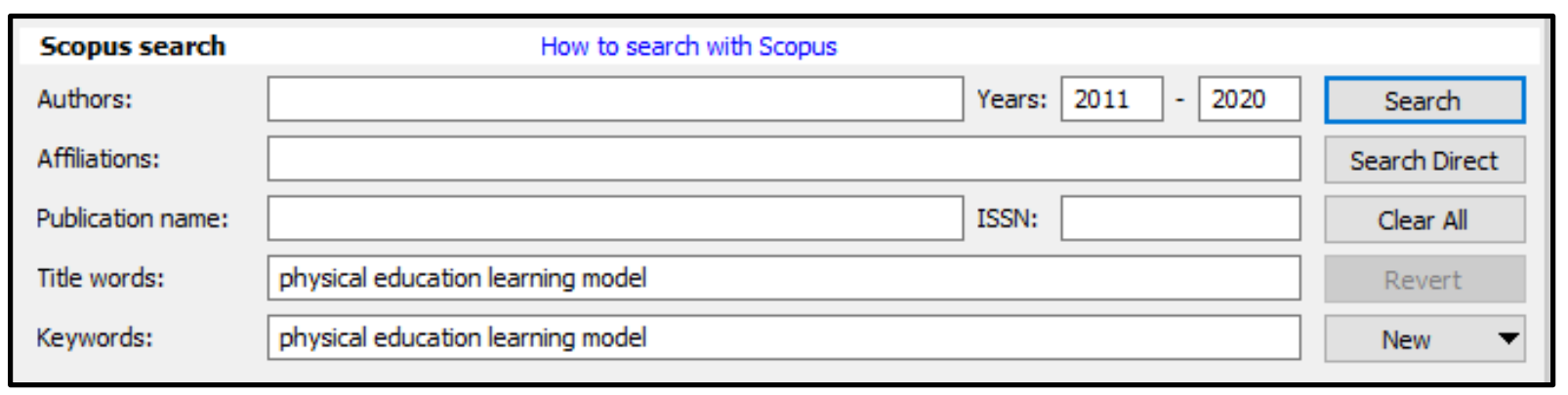

Figure 2. Bibliographies Searching using PoP 


\subsection{Bibliography Exploration and Examination}

In this first step, Publish or Perish (PoP) was used to explore the bibliographic database [48]. PoP is a software that presents search results for publications initiated by Harzing.com. One of its features is the choice of a journal indexing database source. Three criteria are defined when looking for articles using PoP. First, the bibliography was taken from the Scopus database. Scopus database was chosen because it is one of the largest databases that provides peer-reviewed literature [49] with a wider variety of products compared to other repositories [50] and has contributed $70 \%$ more publications compared to WoS [51], [52]. Second, the "title word" and "keyword" columns were filled with four words, "physical education learning model." It was done to obtain the related bibliography on the physical education learning model. Third, the time frame for this bibliographic search had been set to within the last ten years. The time frame is determined by the level of the recentness of the literature review. At the start of the bibliographic search, 34 bibliographies of various types were obtained, including 2 conference proceedings, 5 book chapters, 1 editorial type, and 26 articles. Figure 2 describes the bibliographies searching process using PoP software.

\subsection{Bibliography Filtering}

In this step, the obtained bibliographies were selected by setting the inclusion-exclusion criteria for the bibliography. Three criteria were defined in this study. First, the bibliography has to be a journal article because it is a collection of scientific works published every period and has been peer-reviewed by reviewers or academics [53]. Second, the article should be in English. Third, the articles should have complete metadata information or at least information related to the author, keywords, abstract, and affiliation. Bibliographies that meet the three criteria above were saved in the End-Note X9 software for further meta-data checking process. Based on these criteria, 26 articles were selected. Table 1 presents the bibliographies number from each year generated in PoP.

Table 1. 2011-2020 Bibliography Search Results

\begin{tabular}{cccccc}
\hline Year & Obtained & Percentage & Rejected & Percentage & PTotal \\
\hline 2011 & 1 & $100 \%$ & 0 & $0 \%$ & 1 \\
2012 & 0 & $0 \%$ & 5 & $100 \%$ & 5 \\
2013 & 1 & $100 \%$ & $0 \%$ & 3 & 1 \\
2014 & 3 & $100 \%$ & 0 & $0 \%$ & 3 \\
2015 & 1 & $100 \%$ & 0 & $33 \%$ & 3 \\
2016 & 2 & $67 \%$ & 1 & $33 \%$ & 1 \\
2017 & 2 & $67 \%$ & $0 \%$ & $14 \%$ & 7 \\
2018 & 1 & $100 \%$ & 1 & $0 \%$ & 9 \\
\hline 2019 & 6 & $86 \%$ & 0 & & 34 \\
\hline
\end{tabular}




\subsection{Bibliography Refinement and Completion}

To analyze the bibliographies, the metadata have to be checked and refined because some of the EndNote-extracted metadata were incomplete. Because the missing data are available in the article, the data refinement and completion processes were taken based on the information provided by PoP Software or the article. After the metadata were refined, the bibliography was analyzed

\subsection{Bibliography Analysis}

The bibliography analysis was done based on seven aspects: (1) the development of publications, (2) the journal that contains the most articles on the physical education learning model, (3) the most cited articles, (4) the most-used keywords for the authors in the physical education learning model, (5) collaboration between institutions or affiliations, (6) collaboration between institutes, and (7) author distribution of various locations. VOSviewer was used to analyze the bibliographies. The analysis results were visualized by the software [54], [55]. VOSviewer detects large word counts and offers a variety of visuals or displays with analysis of different observations [44], [45], [46], [56]. Correspondingly, VOSviewer can map the publication, author, or journal according to shared citation platforms or keymaps centered on distribution channels [40], [46]. The types of files that were imported into VOSviewer were from EndNote.

\section{Results}

\subsection{Publication Development Analysis}

Figure 3 shows an increase in the publication trend of Physical Education Learning Model articles of 2011-2020 in terms of quantity. The development indicates an up-and-down with a steady pattern. An up pattern occurred in 2012-2013, 2013-2014, 2015-2016, 2018-2019, 2019-2020. On the other hand, a down pattern occurred in 2011-2012, 2014-2015, 2017-2018. While a steady or horizontal pattern was in 2016-2017. In 2012, there was no publication related to the physical education learning model. Meanwhile, 2020 has the largest number of publications compared to the previous years.

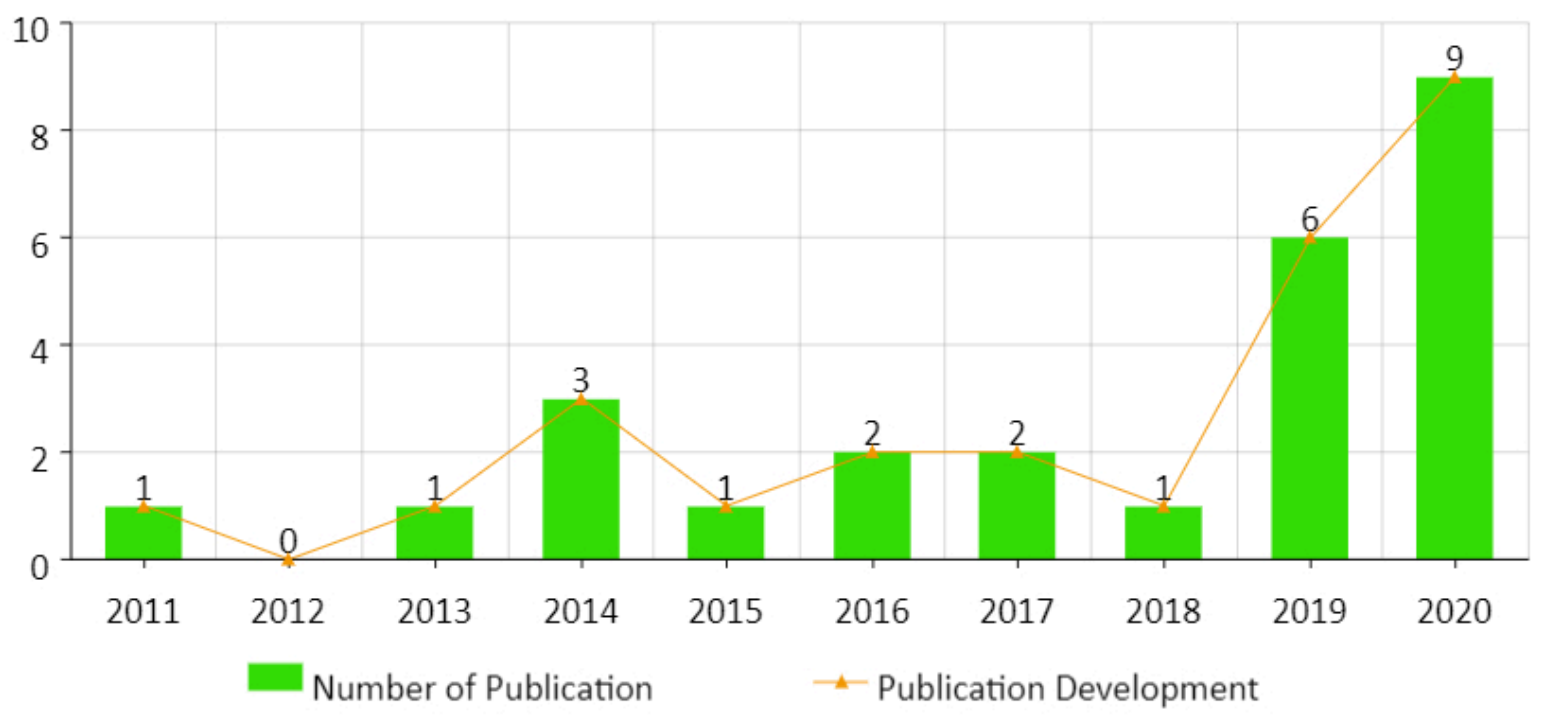

Figure 3. Publication Trend 


\subsection{Citation Development Analysis}

Figure 4 shows that the total of "physical education learning model" related article citations each year. It was found that in 2011-2020, there were 220 citations. The citation pattern was up three times, down five times, and steady one time. It was increasing in 2013-2014,
2014-2015, 2018-2019. On the other hand, it was decreasing in 2011-2012, 2015-2016, 2016-2017, 2017-2018, 2019-2020. Meanwhile, no citations can be found in 2012 and 2013. It was also found that 2015 had the highest number of citations with 51 .

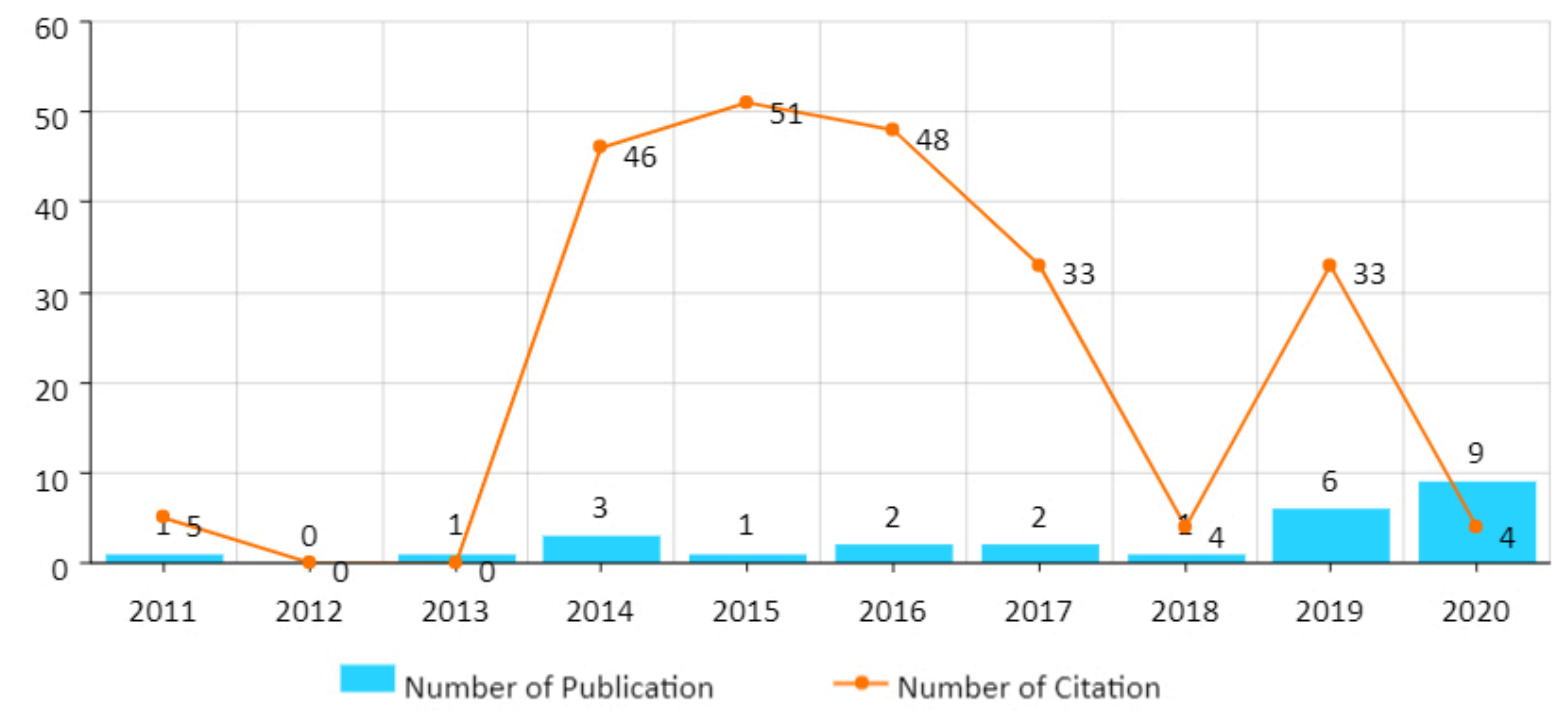

Figure 4. Citation Trend

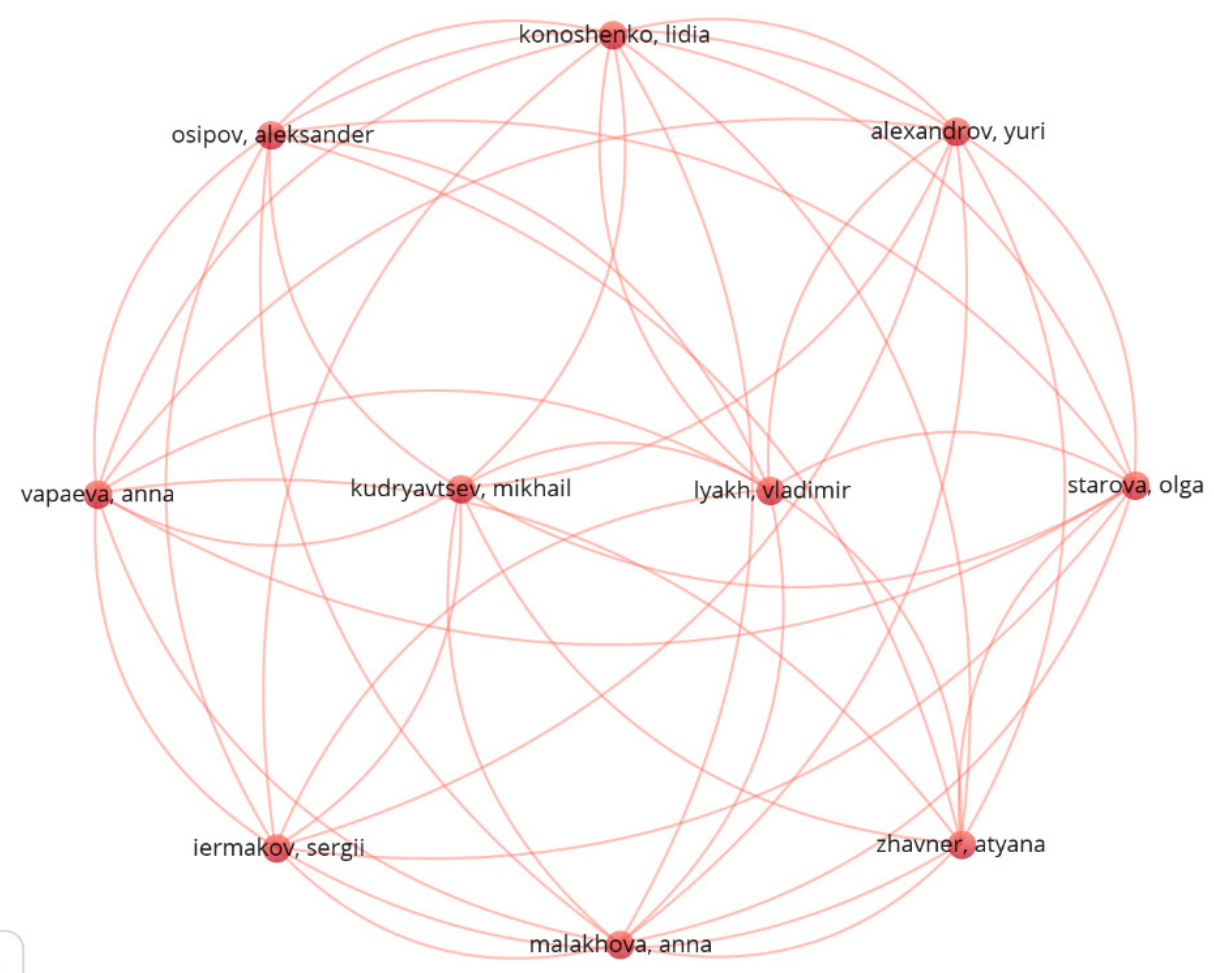

VOSviewer

Figure 5. Author Collaboration Network Visualization 


\subsection{Author Collaboration Analysis}

Table 2. A Total of Author Collaboration Links

\begin{tabular}{ccc}
\hline Author & Documents & Total Link Strength \\
\hline Alexandrov, Yuri & 1 & 9 \\
Iermakov, Sergii & 1 & 9 \\
Konoshenko, Lidia & 1 & 9 \\
Kudryavtsev, & 1 & 9 \\
Mikhail & 1 & 9 \\
lyakh, Vladimir & 1 & 9 \\
Malakhova, Anna & 1 & 9 \\
Osipov, Aleksander & 1 & 9 \\
Starova, Olga & 1 & 9 \\
Vapaeva, Anna & 1 & 9 \\
Zhavner, Atyana & & \\
\hline
\end{tabular}

Of the 26 articles, there are 85 authors, both first and co-authors. Using VOSviewer to analyze the article co-authorship analysis with a minimum occupancy of one document, it was found that there is a cluster with one author and another linked to each other. It was discovered that each of them has nine links. The VOSviewer analysis is presented in Figure 5 and Table 2.

\subsection{Keyword Analysis}

102 keywords were found and used by the author in the articles, which were analyzed with a minimum level of occurrence. From the analysis, 21 keywords in 5 clusters were found to have strong links to physical education. Table 3 shows the categorization of author keywords using color and the number of items. Figure 6 presents the keywords in network visualization.

Table 3. Author Keyword Categorization

\begin{tabular}{cccl}
\hline Cluster & Color & Number of Items & Author Keywords \\
\hline 1 & Red & 5 & Character Values; Cooperation; Discipline; Hard Work; Learning Models \\
2 & Green & 4 & Active Method; Curriculum; Learning Strategy; Problem Solving \\
3 & Blue & 4 & Character Education; Curriculum and teaching; Sports Enthusiastic; Sport Self-Efficacy \\
4 & Yellow & 4 & Digital Age; Identity; Values Compass; Values Fluency Education \\
5 & Purple & 4 & Motivation; Physical Education; Satisfaction Structural Equations \\
\hline
\end{tabular}

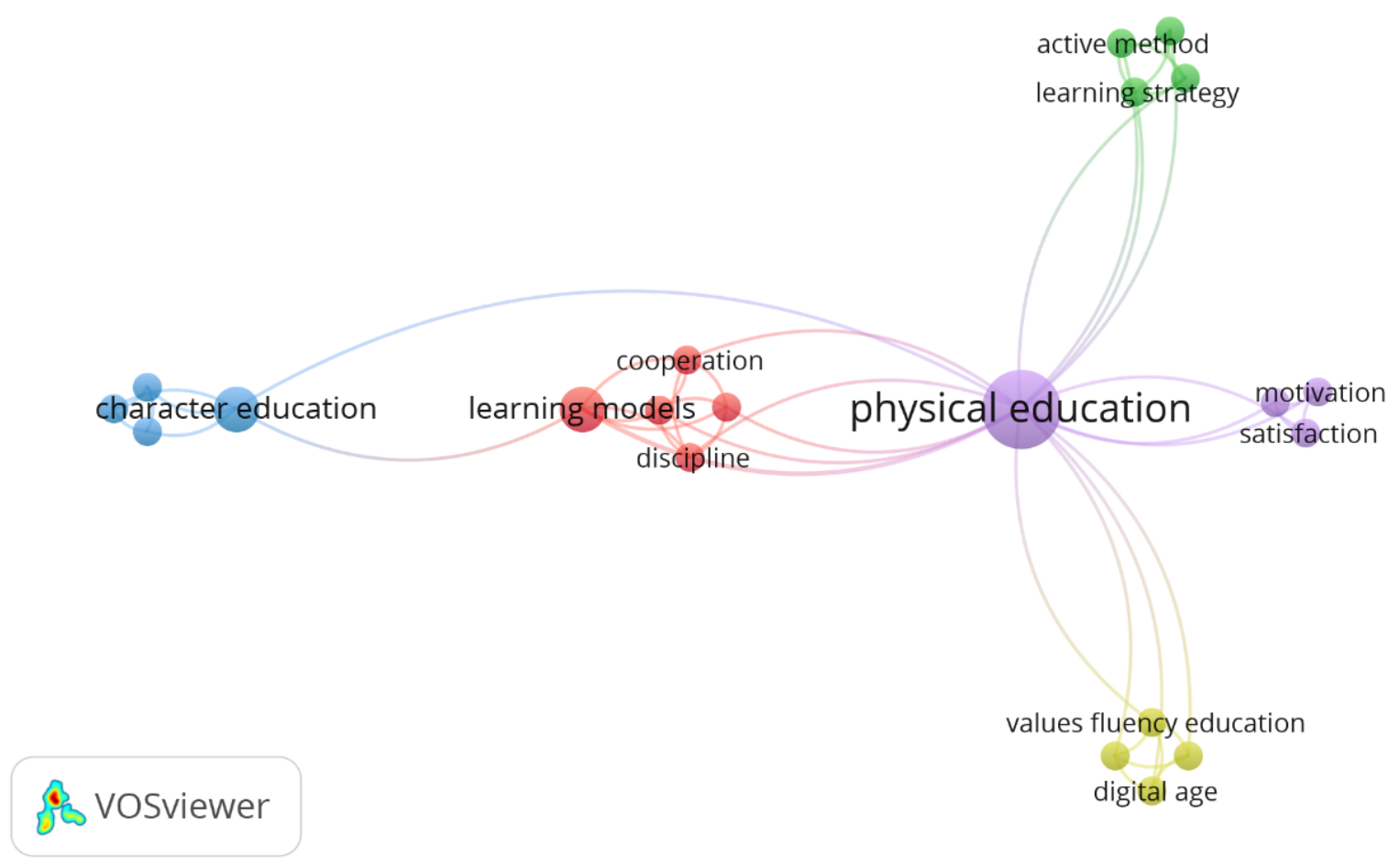

Figure 6. Author Keyword Network Visualization 


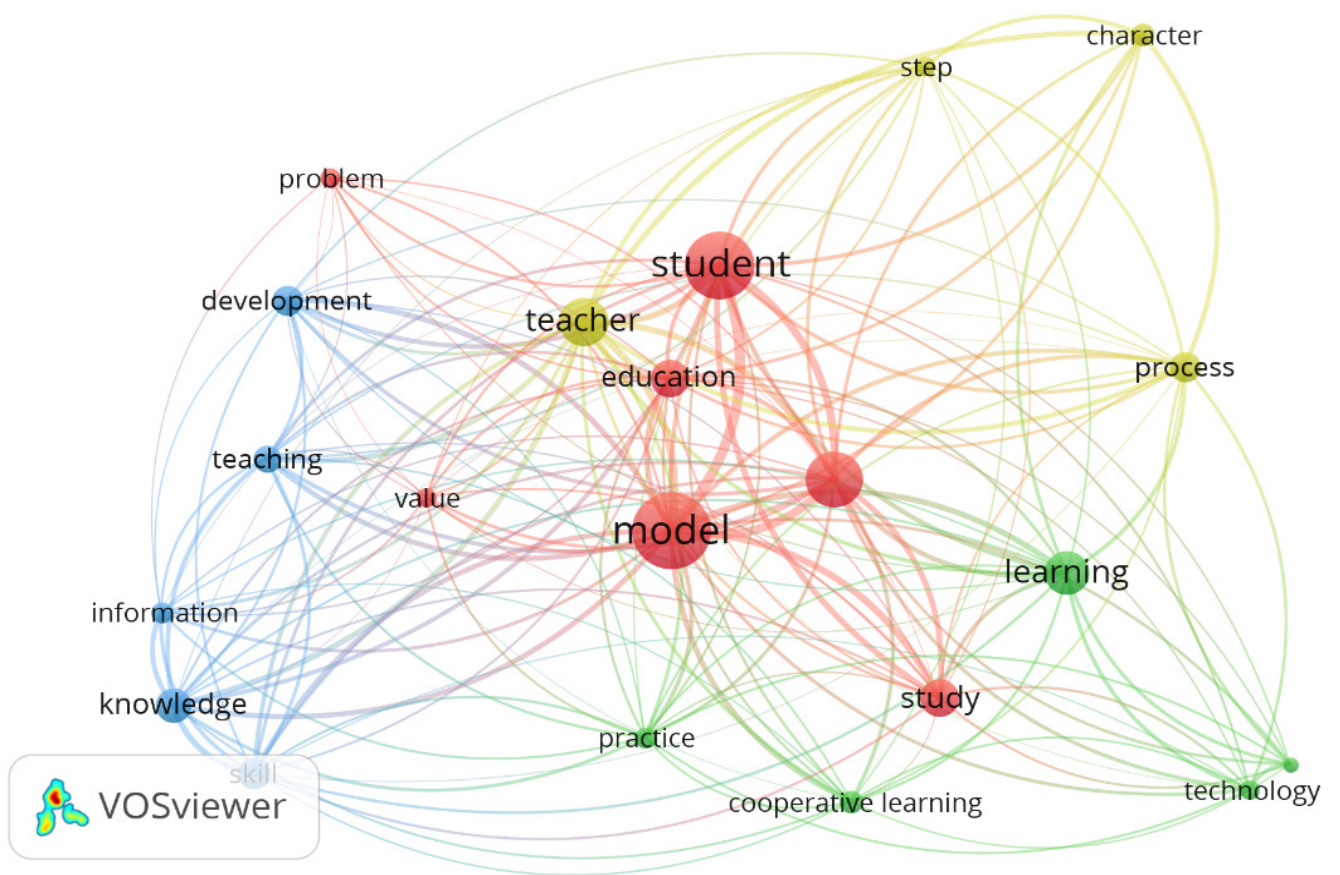

Figure 7. Abstract Terms Network Visualization

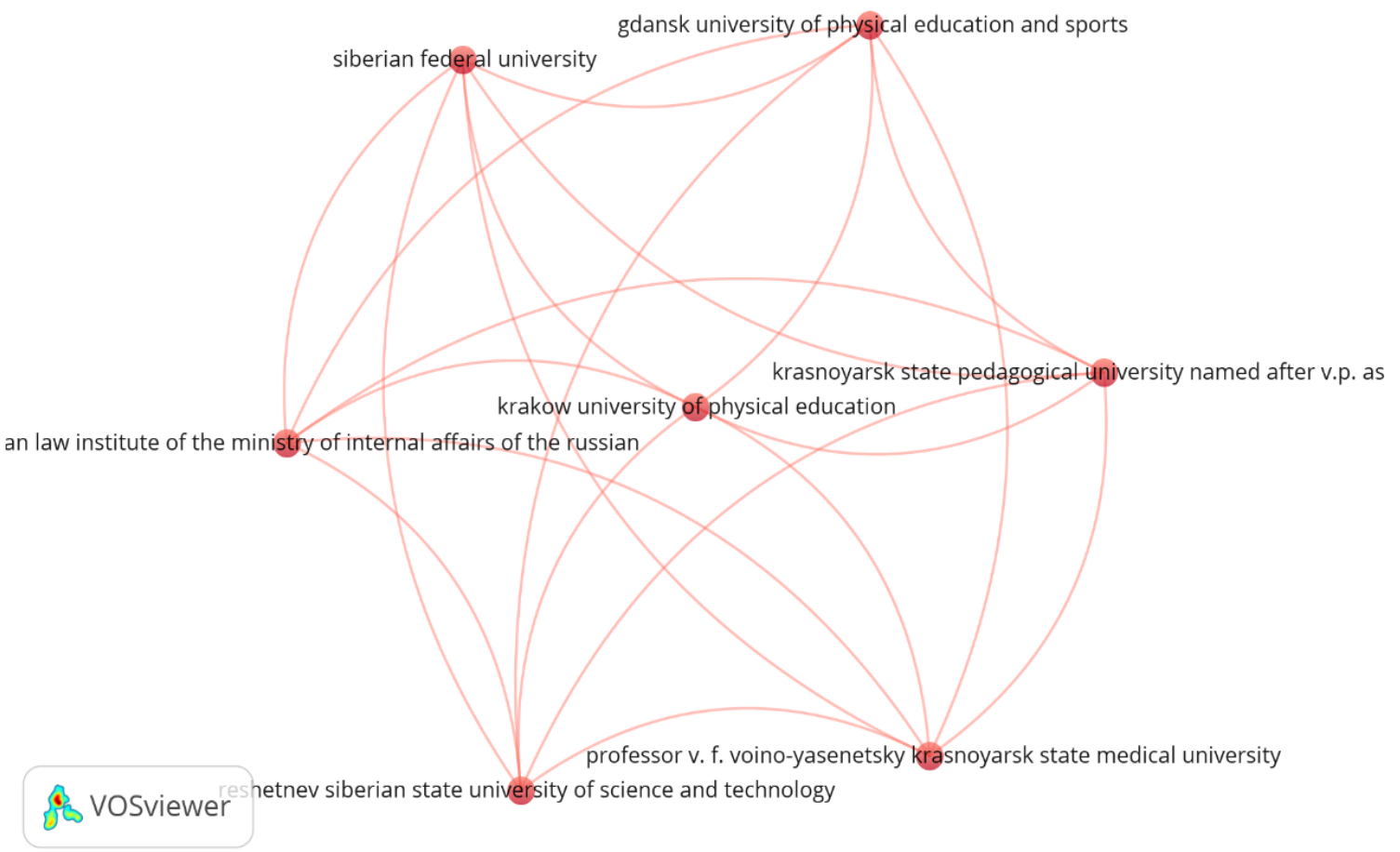

Figure 8. Visualization of the Inter-Institutional Collaboration

\subsection{Abstract Analysis}

Based on the results, 973 related terms were found in the abstracts. By using a minimum of 5 terms occurrence, 34 terms that were found have a strong link. For example, model, student, physical education, character, study, teacher, technology, cooperative learning, and so on. Figure 7 shows a network visualization of the abstract analysis.

\subsection{Institutions Collaboration Analysis}

It was found that there are 57 institutions studying the physical education learning model. Of these 57 institutions, 7 institutions were found to have strong links. The interrelated institutions can be seen in Figure 8. Those seven institutions are Gdansk University of Physical Education and Sports, Krakow University of Physical Education, Krasnoyarsk State Pedagogical University 
Named After V.P. Astafyev, Professor V. F. Voino-Yasenetsky Krasnoyarsk State Medical University, Reshetnev Siberian State University of Science and Technology, Siberian Federal University, and Siberian Law Institute of The Ministry of Internal Affairs of the Russian Federation.

\subsection{Country Analysis}

Table 4 presents the 10 nations of the authors who publish the most articles on physical education learning models in Scopus-indexed journals. The top ten were ordered as follows based on the distribution of authors in the countries: The United States is in the first place, followed by Russia and Indonesia. Figure 9 shows the distribution of countries of authors who publish articles on physical education learning models in Scopus-indexed journals. The author's location was obtained from their address written in the article. Addresses were converted into coordinates using GPS visualizer (gpsvisualizer.com) and the coordinates were extracted using map maker (maps.co).

Table 4. Top Ten Countries with the Most Authors

\begin{tabular}{ccc}
\hline No. & Country & Number of Authors \\
\hline 1 & United States & 12 \\
2 & Russia & 11 \\
3 & Indonesia & 10 \\
4 & Spain & 8 \\
5 & Taiwan & 8 \\
6 & United Kingdom & 7 \\
7 & China & 6 \\
8 & Ecuador & 6 \\
9 & France & 4 \\
10 & Iran & 3 \\
\hline
\end{tabular}




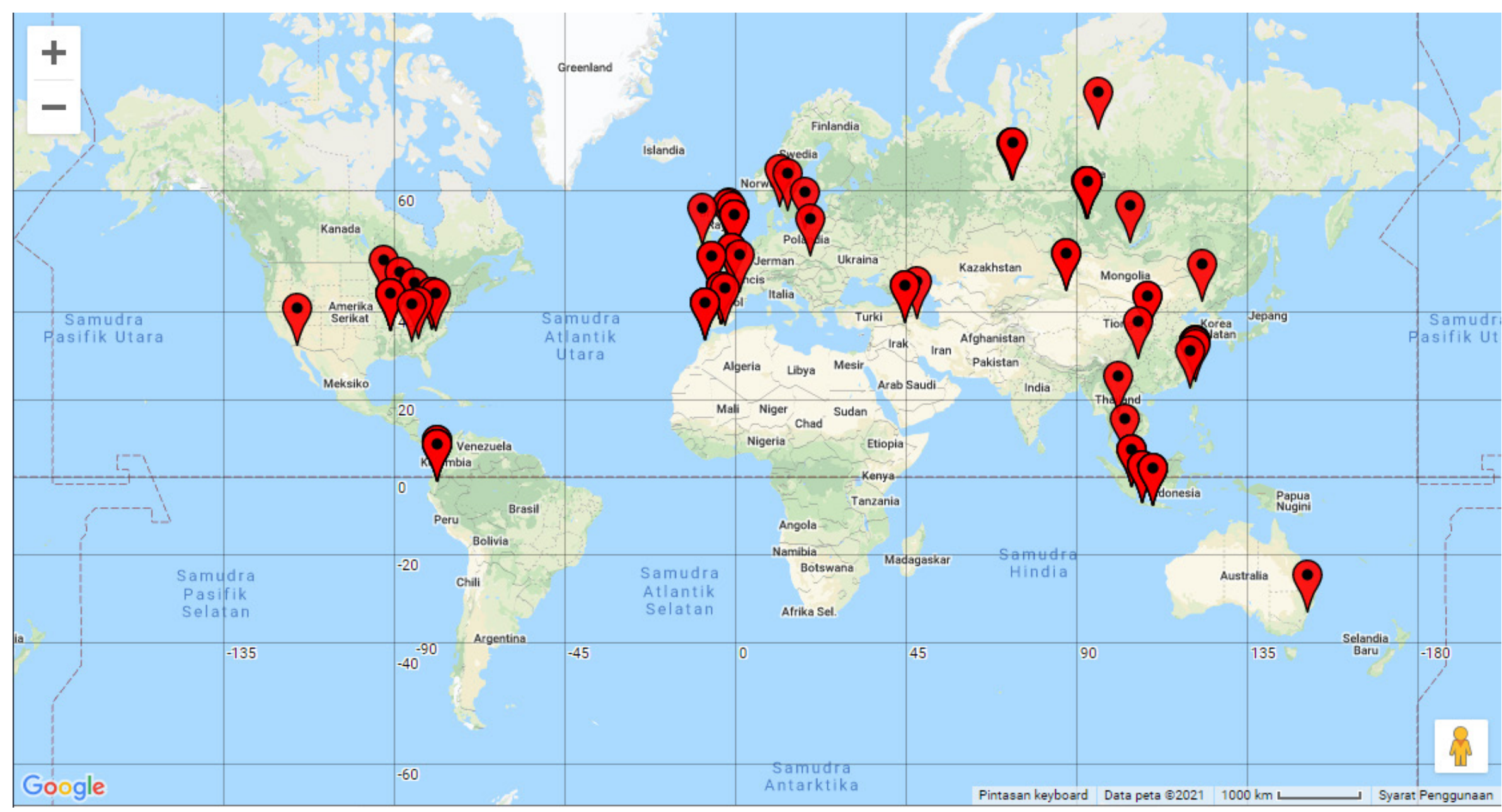

Figure 9. Author Distribution by City/Country 
Table 5. Promoted Character Values

\begin{tabular}{|c|c|c|c|c|c|c|c|c|c|c|}
\hline \multirow{2}{*}{ Character Item } & \multicolumn{10}{|c|}{ Year } \\
\hline & 2011 & 2012 & 2013 & 2014 & 2015 & 2016 & 2017 & 2018 & 2019 & 2020 \\
\hline Independent & 1 & & 1 & 4 & & 2 & 2 & 1 & 6 & 8 \\
\hline Hardworking & & & & 2 & 1 & 2 & 1 & & 4 & 2 \\
\hline Cooperative & & & & 3 & & 1 & 1 & & & 4 \\
\hline Disciplined & & & & 1 & 1 & 2 & & & 1 & 2 \\
\hline Responsible & & & & 1 & & 1 & & & 2 & 2 \\
\hline \multicolumn{11}{|l|}{ Religious } \\
\hline Integrity & & & & & & & & & & 2 \\
\hline Nationalist & & & & & & & & & 1 & \\
\hline
\end{tabular}

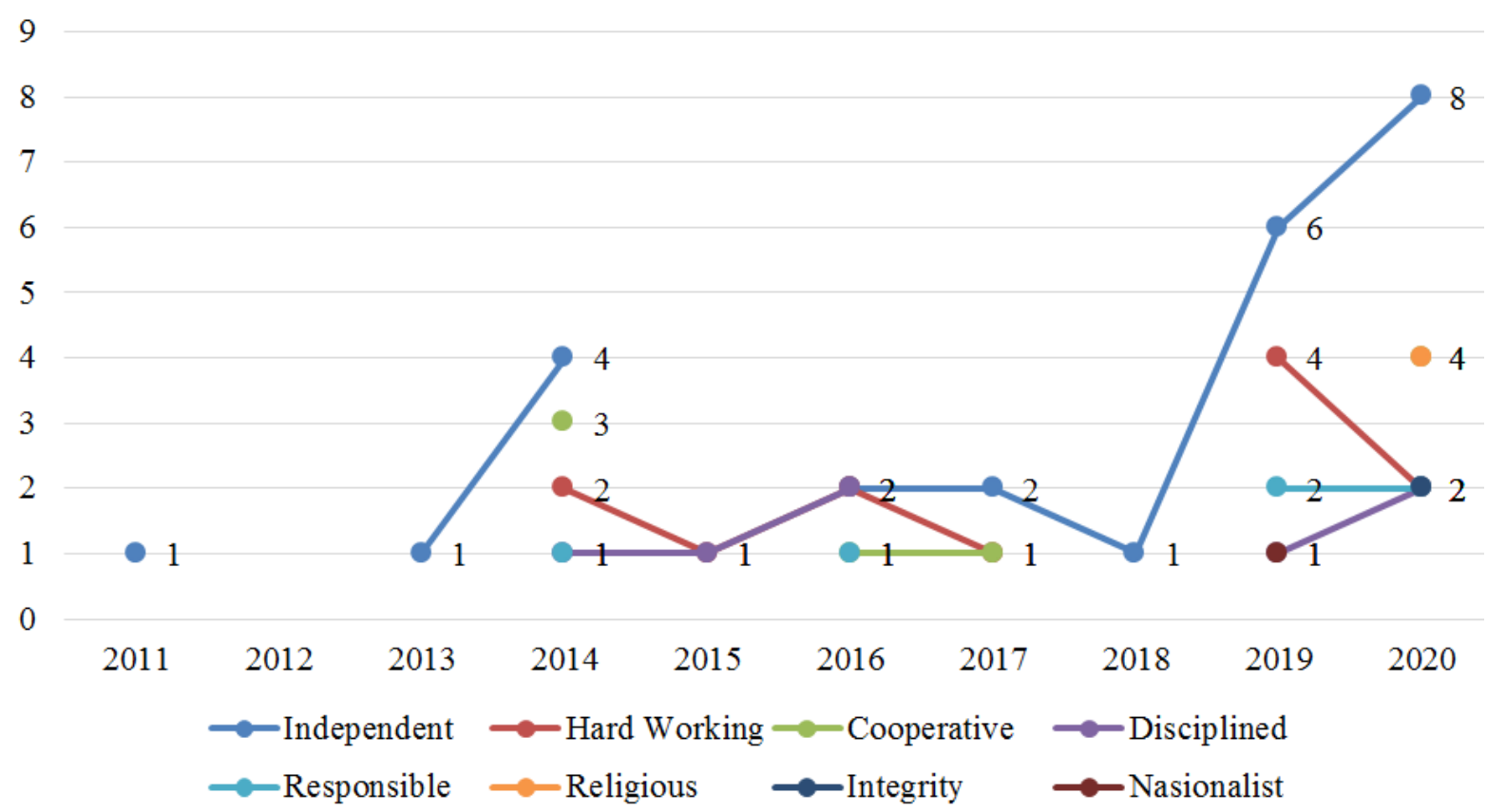

Figure 10. Character Value Distribution by Year

\subsection{Character Values Analysis}

Based on the content analysis of the 26 selected articles, eight characters were promoted: independent, hardworking, cooperative, disciplined, responsible, religious, integrity, and nationalist. Detailed information about the character values are presented in Table 5 and Figure 10.

\section{Discussion}

The findings can be a guide for practitioners and researchers in designing character-based physical education learning models. In terms of the publication trend, although it tends to have an upward trend in terms of quantity, at the time of the writing, there are only 26 articles that discuss character-based physical education learning models in the last decade, which is still quite low compared to other topics. This finding is problematic because the fundamental purpose of education is to help people develop their personalities [17], [57], [58]. Physical education must include character development especially when it comes to nurturing sportsmanship [59]-[61]. This practice is important significant to demonstrate that "sport builds character" is more than just a statement [62].

In addition to the quantity, its quality also needs to be improved. The publication quality can be determined by the citations number. Citations are important because they indicate the impact of the article [63], [64]. When looking at the trend of quotes from papers on physical education models from 2011 to 2020 , the pattern is shifting. It started with a citation in 2011 and finished with four citations in 2020. On the other hand, 2015 was the year with the most citations with 51 [65]. This article highlights Student-Centered Physical Education as a model for nurturing independent, disciplined, and hardworking character in students [55]. The high number of citations in the article demonstrates that the article promoting character values has fascinated a wide range of researchers. This 
finding should encourage other researchers who will publish their studies.

In addition to citations, a collaboration between researchers with different affiliates in various countries can provide an overview to other researchers concerning the issue of physical education in a country or region. This is an opportunity for international researchers to collaborate and publish an article. Collaboration at the international level is crucial because foreign publications could increase a country's prestige through diplomacy in terms of educational and scientific excellence [66].

Academics can conduct bibliometric studies to understand other researchers' studies to improve the quality and number of publications related to physical education learning models. At least, it could be started with keyword research. A keyword analysis is crucial since it aids in the process of locating information [67]. As shown in this study, the term "physical education" in physical education learning models is related to curriculum, motivation, values, fluency, education, cooperation, and character education.

Abstract analysis can reveal more information as the development of keyword analysis. For example, information on research issues, contexts, results, and recommendations is provided in the abstract. This study analyzes abstracts using VOSviewer to detect frequently used phrases. Using the VOSviewer, it was revealed that 973 terms are used in abstracts. In addition, by using the occurrence of at least 5,34 terms with strong relationships were found, including model, student, physical education, character, study, teacher, and cooperative learning. Researchers can provide insight into the relationship between these terms. Following this phase, systematic literature reviews can be conducted. For example, this study discovers 8 characters that are being discussed in the 26 selected papers. Independent, hardworking, cooperative, disciplined, responsible, religious, integrity, and nationalist are the eight characters. In addition, several character-based physical education learning models were identified, including mixed learning, practical teaching, cooperative learning, student-centered physical education, practical-based, evaluation, inclusive learning, movement-oriented, teaching personal and responsibility, sports education, and traditional teaching models.

Considering the finding, teachers are required to continuously improve their literacy skills by conducting this bibliometric study. As they work to improve their skills, this becomes increasingly vital. The success of physical education is in line with instructors' ability to apply and improve the learning model.

\section{Conclusions}

The eight research questions have been answered and the conclusion has been drawn, as follows:
1) The trend of publication has an up-and-down pattern. The majority of the trend took place in 2020 with nine articles. In general, there had been a rise in the publication of studies on physical education learning models between 2011 and 2020 .

2) The citation trend has an up-and-down pattern and has stabilized. With 51 citations, 2013 was the year with the most citations, indicating that an article was of high quality.

3) Authors' collaboration in writing physical education learning model articles was infrequent with only one cluster with ten authors who collaborate with other authors.

4) 102 keywords can be found in articles related to physical education learning models. Among them, 21 keywords have a strong association: character values, cooperation, discipline, hard work, learning models, active method, curriculum, learning strategy, problem solving, character education, curriculum and teaching, sports enthusiastic, sport self-efficacy digital age, identity compass, values fluency education, motivation, physical education, and satisfaction structural equations.

5) There are 34 terms with a strong association among the 973 abstract concepts, including model (66 events), student (54 events), physical education (38 events), and teacher (31 events).

6) It was revealed that there are 57 institutions studying physical education learning model and only seven institutions show strong collaboration: Gdansk University of Physical Education and Sports, Krakow University of Physical Education, Krasnoyarsk State Pedagogical University Named After V.P. Astafyev, Professor V. F. Voino-Yasenetsky Krasnoyarsk State Medical University, Reshetnev Siberian State University of Science and Technology, Siberian Federal University, and Siberian Law Institute of The Ministry of Internal Affairs of the Russian Federation.

7) The United States, Russia, and Indonesia were the three countries that contributed the most to physical education learning model articles focused on character development.

8) It was found that there are 8 characters that are being promoted in physical education learning model articles: independent, hardworking, collaboration, good discipline, responsible, religious, good integrity, nationalist with varied learning models: mixed learning, practical teaching model, cooperative learning, student-centered physical education model, model-based practice, evaluation model, inclusive learning model, movement-oriented exercise model, teaching personal and responsibility, sports education model, and traditional teaching model.

Based on these answers, it is expected that this bibliometric study would provide significant scientific knowledge and point the way for further studies. As a result, 
it is critical for academics and practitioners of physical education to be able to use bibliometric studies as part of a genuine attempt to develop studies in the subject. Mastery of bibliometric studies also demonstrates the literacy skills required of physical education teachers in dealing with the issues of 21 st-century learning.

\section{Limitation}

In various ways, the bibliometric investigation in this study is still limited. The study is more focused on the context of promoting character qualities in the physical education learning model from the standpoint of the study. From the software aspect, this study used VOSviewer. Therefore, different areas and focuses of this study can still be further explored.

\section{Acknowledgements}

We would like to express our gratitude to the many parties who have supported this study, especially the Indonesian University of Education's Institute of Research and Community Service, which has provided funding for this study as mentioned in letter No. 644/UN40.LP/PT.01.03/2021.

\section{REFERENCES}

[1] Arweck, E., Nesbitt, E., \& Jackson, R. (2005). Common values for the common school? Using two values education programmes to promote 'spiritual and moral development.' Journal of Moral Education, 34(3), 325-342.

[2] Narvaez, D., \& Lapsley, D. K. (2008). Teaching moral character: Two alternatives for teacher education. The Teacher Educator, 43(2), 156-172.

[3] Figley, G. E. (1984). Moral education through physical education. Quest, 36(1), 89-101. https://doi.org/10.1080/00 336297.1984.10483804

[4] Mouratidou, K., Goutza, S., \& Chatzopoulos, D. (2007). Physical education and moral development: An intervention programme to promote moral reasoning through physical education in high school students.

[5] Kleiber, D. A., \& Roberts, G. G. (1981). The effects of sport experience in the development of social character: An exploratory investigation. Journal of Sport and Exercise Psychology, 3(2), 114-122.

[6] Rees, C. R. (1997). Still building American character: Sport and the physical education curriculum. The Curriculum Journal, 8(2), 199-212.

[7] Reid, H. L. (2007). Sport and moral education in Plato's Republic. Journal of the Philosophy of Sport, 34(2), 160 175 .
[8] Doty, J. (2006). Sports build character?! Journal of College and Character, 7(3), 1-9.

[9] Rudd, A. (2005). Which" character" should sport develop? The Physical Educator, 62(4), 205-212.

[10] Sage, G. (1998). Does sport affect character development in athletes? Journal of Physical Education, Recreation \& Dance, 69(1), 15-18.

[11] Suherman, A., Supriyadi, T., \& Cukarso, S. H. I. (2019). Strengthening National Character Education through Physical Education: An Action Research in Indonesia. International Journal of Learning, Teaching and Educational Research, 18(11). https://doi.org/10.26803/ijlte r.18.11.8European Physical Education Review, 13(1), 41-56. https://doi.org/10.1177/1356336X07072675

[12] Y.-H. Pan, C.-H. Huang, I. Lee, and W.-T. Hsu, "Comparison of learning effects of merging TPSR respectively with Sport Education and Traditional teaching model in high school physical education classes," Sustainability, vol. 11, no. 7, p. 2057, 2019, doi: 10.3390/su11072057.

[13] Sujarwo, Suharjana, H. A. Rachman, Siswantoyo, and J. Saputra, "Identifying the factor structure of physical education learning model and its effectiveness in improving the character values of students," J. Adv. Res. Dyn. Control Syst., vol. 12, no. 6, pp. 766-775, 2020, doi: 10.5373/JARDCS/V12I6/S20201092.

[14] J. M. Fernandez-Batanero, M. Montenegro-Rued, J. Fernandez-Cerero, and I. Garcia-Martinez, "Impact of the Information and Communication Technologies on the Education of Students with Down Syndrome: A Bibliometric Study (2008-2018)," Eur. J. Educ. Res., vol. 9, no. 1, pp. 79-89, 2019, doi: 10.12973/eu-jer.9.1.79.

[15] W. O. Otchie and M. Pedaste, "Using Social Media for Learning in High Schools: A Systematic Literature Review," Eur. J. Educ. Res., vol. 9, no. 2, pp. 889-903, 2020, doi: 10.12973/eu-jer.9.2.889.

[16] E. Campbell, Teaching ethically as a moral condition of professionalism. 2014.

[17] T. Lickona and M. Davidson, Smart \& good high schools: Integrating excellence and ethics for success in school, work, and beyond. Center for the 4th and 5th Rs/Character Education Partnership, 2005.

[18] K. Ryan, K. E. Bohlin, and S. N. McDonnell, Building character in schools: Practical ways to bring moral instruction to life. Jossey-Bass San Francisco, 1999.

[19] S. R. Rindrayani, "The Implementation of Character Education in Indonesia High School Curriculum Program," Univers. J. Educ. Res., vol. 8, no. 1, pp. 304-312, 2020, doi: 10.13189/ujer.2020.080137.

[20] M. DeBusk and D. Hellison, "Implementing a physical education self-responsibility model for delinquency-prone youth," J. Teach. Phys. Educ., vol. 8, no. 2, pp. 104-112, 1989, doi: 10.1123/jtpe.8.2.104.

[21] M. Metzler, Instructional models in physical education. Routledge, 2017.

[22] S. C. Wortham, Early childhood curriculum: Developmental bases for learning and teaching. Kevin M. Davis, 2006. 
[23] Z. Yun-fei, "Reflection on Carrying out Club Model in Physical Education Teaching of Colleges and Universities," JOURNAL-SHANGHAI Phys. Educ. INSTITUTE., vol. 28, pp. 92-94, 2004.

[24] B. Joyce, M. Weil, and E. Calhoun, Models of Teaching (Eight Edition). New Jersey: Allyn and Bacon, 2009.

[25] T. Tayeb, "ANALISIS DAN MANFAAT MODEL PEMBELAJARAN," AULADUNA J. Pendidik. Dasar Islam, vol. 4, no. 2, pp. 48-55, 2017.

[26] D. Clarke and H. Hollingsworth, "Elaborating a model of teacher professional growth," Teach. Teach. Educ., vol. 18, no. 8, pp. 947-967, 2002, doi: 10.1016/S0742-051X(02)000 $53-7$.

[27] Jay B Nash, "The Rôle of Physical Education in Character Education," J. Health Phys. Educ., vol. 4, no. 3, pp. 28-69, 1933, doi: 10.1080/23267240.1933.10625629.

[28] A. Maksum, "Kualitas guru Pendidikan Jasmani di sekolah: Antara harapan dan kenyataan," 2010.

[29] K. Castle, "Autonomy through pedagogical research," Teach. Teach. Educ., vol. 22, no. 8, pp. 1094-1103, 2006, doi: 10.1016/j.tate.2006.07.001.

[30] M. James and R. McCormick, "Teachers learning how to learn," Teach. Teach. Educ., vol. 25, no. 7, pp. 973-982, 2009.

[31] J. Nisbet and J. Shucksmith, Learning Strategies; e Book. London: Routledge, 2017.

[32] J. D. Novak and D. B. Gowin, Learning how to learn. Cambridge University Press, 1984.

[33] M. R. Olson and C. J. Craig, “Opportunities and challenges in the development of teachers' knowledge: The development of narrative authority through knowledge communities," Teach. Teach. Educ., vol. 17, no. 6, pp. 667684, 2001, doi: 10.1016/s0742-051x(01)00023-3.

[34] T. Supriyadi, J. Julia, and P. D. Iswara, "Phonological Interference in Reciting Al-Qur'an: A Critical Reflection on the Learning of Al-Qur'an Phonology through Action Research," Int. J. Learn. Teach. Educ. Res., vol. 18, no. 9, 2019, doi: 10.26803/ijlter.18.9.3.

[35] F. A. J. Korthagen, "Situated learning theory and the pedagogy of teacher education: Towards an integrative view of teacher behavior and teacher learning," Teach. Teach. Educ., vol. 26, no. 1, pp. 98-106, 2010, doi: 10.1016/j.tate.2009.05.001.

[36] C. Penlington, "Dialogue as a catalyst for teacher change: A conceptual analysis," Teach. Teach. Educ., vol. 24, no. 5, pp. 1304-1316, 2008, doi: 10.1016/j.tate.2007.06.004.

[37] B. Avalos, "Teacher Professional Development in Teaching and Teacher Education Over Ten Years," Teach. Teach. Educ., vol. 27, no. 1, pp. 10-20, 2011, doi: 10.1016/j.tate.2010.08.007.

[38] J. M. F. Batanero, M. M. R. Rebollo, and M. M. Rueda, "Impact of ICT on students with high abilities. Bibliographic review (2008-2018)," Comput. Educ., vol. 137, pp. 48-58, 2019, doi: 10.1016/j.compedu.2019.04.007.

[39] J. A. Garza-Reyes, "Lean and green-a systematic review of the state of the art literature," J. Clean. Prod., vol. 102, pp. 18-29, 2015, doi: 10.1016/j.jclepro.2015.04.064.

[40] M. N. Hudha, I. Hamidah, A. Permanasari, A. G. Abdullah, I. Rachman, and T. Matsumoto, "Low Carbon Education: A Review and Bibliometric Analysis.," Eur. J. Educ. Res., vol. 9, no. 1, pp. 319-329, 2020.

[41] A. Mathankar, "Bibliometrics: An overview," Int. J. Libr. Inf. Sci., vol. 7, no. 3, pp. 9-15, 2018, doi: 10.34218_2Fijlis.7.3 .2018 .

[42] İ. Șeref and B. Karagöz, “A bibliometric profile of literature of Turkish language education-teaching: A case study of 9th International Language Education-Teaching Conference," Eur. J. Altern. Educ. Stud., 2019, doi: 10.5281/zenodo.2636 993.

[43] İ. Şeref and B. Karagöz, "An Evaluation of Turkish Education Academic Field: Bibliometric Analysis Based on Web of Science Database Türkçe Eğitimi Akademik Alanına İlişkin Bir Değerlendirme: Web of Science Veri Tabanına Dayalı Bibliyometrik İnceleme," J. Lang. Educ. Res., vol. 5, no. 2, pp. 213-231, 2019, doi: 10.31464/jlere.578224.

[44] N. J. Van Eck and L. Waltman, "Software survey: VOSviewer, a computer program for bibliometric mapping," Scientometrics, vol. 84, no. 2, pp. 523-538, 2010, doi: 10.1007/s11192-009-0146-3.

[45] N. J. Van Eck and L. Waltman, "Visualizing bibliometric networks," in Measuring scholarly impact, Springer, 2014, pp. 285-320.

[46] I. Zupic and T. Čater, "Bibliometric methods in management and organization," Organ. Res. Methods, vol. 18, no. 3, pp. 429-472, 2015.

[47] J. Julia, E. Supriatna, I. Isrokatun, I. Aisyah, R. Nuryani, and A. A. Odebode, "Moral Education (2010-2019): A Bibliometric Study (Part 1)," Univers. J. Educ. Res., vol. 8, no. 6, pp. 2554-2568, 2020, doi: 10.13189/ujer.2020.08063 9 .

[48] J. Julia et al., "Flipped Classroom Educational Model (2010-2019): A Bibliometric Study," Eur. J. Educ. Res., vol. 9, no. 4, pp. 1377-1392, 2020, doi: 10.12973/eu-jer.9.4.137 7.

[49] B. S. Ballew, "Elsevier's scopus ${ }^{\circledR}$ database," J. Electron. Resour. Med. Libr., vol. 6, no. 3, pp. 245-252, 2009, doi: $10.1080 / 15424060903167252$.

[50] L. Salisbury, "Web of Science and Scopus: A comparative review of content and searching capabilities," Charlest. Advis., vol. 11, no. 1, pp. 5-18, 2009.

[51] C. López-Illescas, F. de Moya-Anegón, and H. F. Moed, "Coverage and citation impact of oncological journals in the Web of Science and Scopus," J. Informetr., vol. 2, no. 4, pp. 304-316, 2008.

[52] M. Shareefa and V. Moosa, "The Most-Cited Educational Research Publications on Differentiated Instruction: A Bibliometric Analysis.," Eur. J. Educ. Res., vol. 9, no. 1, pp. 331-349, 2020.

[53] M. B. N. Wajdi, M. Ali, and V. N. S. Lestari, "Definisi Dan Karakteristik Makalah,” 2017, doi: 10.31219/osf.io/hw5m8.

[54] F. J. Martínez-López, J. M. Merigó, J. C. Gázquez-Abad, 
and J. L. Ruiz-Real, "Industrial marketing management: Bibliometric overview since its foundation," Ind. Mark. Manag., vol. 84, pp. 19-38, 2020.

[55] N. Shukla, J. M. Merigó, T. Lammers, and L. Miranda, "Half a century of computer methods and programs in biomedicine: A bibliometric analysis from 1970 to 2017," Comput. Methods Programs Biomed., vol. 183, p. 105075, 2020.

[56] I. Rafols, L. Leydesdorff, A. O’Hare, P. Nightingale, and A. Stirling, "How journal rankings can suppress interdisciplinary research: a comparison between innovation studies and business \& management," Res. Policy, vol. 41, no. 7, pp. 1262-1282, 2012, doi: 10.1016/j.respol.2012.03.0 15.

[57] A. Lumpkin, "Teachers as role models teaching character and moral virtues," J. Phys. Educ. Recreat. Danc., vol. 79, no. 2, pp. 45-50, 2008, doi:10.1080/07303084.2008.105981 34.

[58] B. Crum, "Character Development through Sport Empirical Evidence or Whisful Thinking?" Makalah, 2006.

[59] M. P. Giebink and T. L. McKenzie, "Teaching sportsmanship in physical education and recreation: An analysis of interventions and generalization effects," $J$. Teach. Phys. Educ., vol. 4, no. 3, pp. 167-177, 1985.

[60] C. G. Pennington, "Moral development and sportsmanship in physical education and sport," J. Phys. Educ. Recreat. Danc., vol. 88, no. 9, pp. 36-42, 2017.
[61] Y. Koc, "Relationships between the Physical Education Course Sportsmanship Behaviors with Tendency to Violence and Empathetic Ability.," J. Educ. Learn., vol. 6, no. 3, pp. 169-180, 2017.

[62] Maksum, A., "Olahraga membentuk karakter: Fakta atau mitos," J. Ordik, vol. 3, no. 1, pp. 23-30, 2005.

[63] J. Ben Arbaugh and A. Hwang, "What are the 100 most cited articles in business and management education research, and what do they tell us?," Organ. Manag. J., vol. 12, no. 3, pp. 154-175, 2015, doi: 10.1080/15416518.2015.1073135.

[64] C. Walter and V. Ribière, "A citation and co-citation analysis of 10 years of KM theory and practices," Knowl. Manag. Res. Pract., vol. 11, no. 3, pp. 221-229, 2013, doi: 10.1057/kmrp.2013.25.

[65] V. Goodyear and D. Dudley, “'I'm a Facilitator of Learning!' Understanding What Teachers and Students Do Within Student-Centered Physical Education Models," Quest, vol. 67, no. 3, pp. 274-289, 2015, doi:10.1080/00336297.2015.1 051236 .

[66] N. B. Subekti, "Rangking Publikasi Ilmiah Internasional Indonesia," Sindo, Jakarta, 2015.

[67] M. Muntashir and E. Erida, "Analisis sitiran dan pemetaan deskriptor terhadap disertasi Program Pascasarjana Universitas Islam Negeri Imam Bonjol," Shaut Al-Maktabah J. Perpustakaan, Arsip dan Dokumentasi, vol. 10, no. 1, pp. $1-26,2018$. 